\title{
Protein Fractions of Pearl Millet Submitted to Different Nitrogen Doses and Cutting Ages
}

\author{
Oscar L. Faria Júnior \\ Escola de Veterinária e Zootecnia, Universidade Federal de Goiás, Campus II - Samambaia, \\ ZIP-CODE: 74001-970; P.O. BOX: 131; Goiânia, Goiás, Brasil \\ Aldi F. de S. França \\ Escola de Veterinária e Zootecnia, Universidade Federal de Goiás, Campus II - Samambaia, \\ ZIP-CODE: 74001-970; P.O. BOX: 131; Goiânia, Goiás, Brasil \\ Alzira G. da Silva-Pause \\ Universidade Federal do Pará - Campus Marabá. Campus II (Folha 17 Quadra 4 Lote \\ especial) Nova Marabá, ZIP-CODE: 68505-080 - Marabá, Pará, Brasil \\ Eliane S. Miyagi \\ Escola de Veterinária e Zootecnia, Universidade Federal de Goiás, Campus II - Samambaia, \\ ZIP-CODE: 74001-970; P.O. BOX: 131; Goiânia, Goiás, Brasil \\ Hugo J. M. C. Peron
}

Escola de Veterinária e Zootecnia, Universidade Federal de Goiás, Campus II - Samambaia, ZIP-CODE: 74001-970; P.O. BOX: 131; Goiânia, Goiás, Brasil

Emmanuel Arnhold

Escola de Veterinária e Zootecnia, Universidade Federal de Goiás, Campus II - Samambaia, ZIP-CODE: 74001-970; P.O. BOX: 131; Goiânia, Goiás, Brasil

Alessandra G. Mascarenhas

Escola de Veterinária e Zootecnia, Universidade Federal de Goiás, Campus II - Samambaia, ZIP-CODE: 74001-970; P.O. BOX: 131; Goiânia, Goiás, Brasil

Daniel S. Corrêa (Corresponding author)

Escola de Veterinária e Zootecnia, Universidade Federal de Goiás, Campus II - Samambaia, ZIP-CODE: 74001-970; P.O. BOX: 131; Goiânia, Goiás, Brasil

E-mail: daniel.staciarini@terra.com.br

Received: December 17, 2012 Accepted: January 3, 2013 Published: January 24, 2013

doi:10.5296/jas.v1i1.2890 URL: http://dx.doi.org/10.5296/ jas.v1i1.2890 


\section{Abstract}

The objective of this study was to characterize and identify the protein fractions of two cultivars of pearl millet (Pennisetum glaucum) - ADR-300 and cv. BN-1 - submitted to different nitrogen doses $\left(0,50,100\right.$ and $\left.150 \mathrm{~kg} \cdot \mathrm{ha}^{-1}\right)$ at three cutting ages. The experimental design used was randomized blocks with a $4 \times 3$ factorial treatment structure, with three repetitions. The crude protein concentration (CP) and the protein fractions $A, B_{1}, B_{2}, B_{3}$ and $\mathrm{C}$ of the pearl millet cultivars were evaluated by the Cornell Net Carbohydrate and Protein System. The CP concentrations differed according to the cultivars, with variation between the treatments of $14.01 \%$ to $23.29 \%$ for ADR-300 and $11.82 \%$ to $19.29 \%$ for BN-1. Fraction A $(\mathrm{P}<0.05)$ differed for the two cultivars, with variations also observed in the $\mathrm{B}_{1}, \mathrm{~B}_{2}$ and $\mathrm{B}_{3}$ fractions in function of the treatments applied. Fraction $\mathrm{C}(\mathrm{P}<0.05)$ differed among treatments only on the first cutting, for all doses for the two cultivars evaluated. The nitrogen doses and cutting age influenced the composition of the protein fractions.

Keywords: crude protein, nitrogen fractionation, nitrogen fertilization, Pennisetum glaucum, ruminant nutrition.

\section{Introduction}

Brazilian livestock breeding is closely linked to exploitation of natural and cultivated pastures, so high productivity of forage grasses is one of the main factors responsible for the success of this activity. Annual grasses that mature in the hot season, such as millet (Pennisetum glaucum (L) R. Br.), are important elements in grazing systems that aim to obtain high forage yield and animal productivity in relation to area. According to Moojen et al. (1999), this species adapts well to the climate conditions in the Midwest region of Brazil and is able to produce a large quantity of good-quality forage in a short time. Due to the variability among genotypes, the choice of cultivar is an important decision and should consider genetic factors of the plant and regional edaphoclimatic factors. Millet has excellent nutritional value, good palatability and digestibility and is nontoxic to animals at all growing stages. Benedetti (1999) evaluated millet grown in a broadcast seeding system and measured average crude protein (CP) concentrations between 8.0 and 9.2\% after 30 days of growth, while at the end of the pasture cycle the levels varied from 3.2 to $4.6 \%$, which limited consumption.

According to Corsi (1995), nitrogen is the main component of the protoplasm after water. It acts in various metabolic processes, composing part of the hormones, and directly affects the photosynthesis process through its presence in the chlorophyll molecule. The application of $\mathrm{N}$ on forage plants can stimulate production of mass, and if there are no limitations due to production factors and lack of other nutrients, the increments can be very high (Silva et al., 2008). Kollet et al. (2006) evaluated the qualitative characteristics of pearl millet cultivars at three cutting ages: 35, 42 and 49 days, with application of $20 \mathrm{~kg} \mathrm{ha}^{-1}$ of $\mathrm{N}$, incorporated in the soil before planting, plus side dressing of $60 \mathrm{~kg}$.ha- ${ }^{-1}$ applied when the plants reached $10 \mathrm{~cm}$ in height, measuring CP values of 13.9 to $20.6 \%$.

Advances in the knowledge of ruminant nutrition, especially in the past decade, have enabled the development of new feeding systems and methods of assessing livestock feed to 
maximize use of forage plants. The supply of ruminants' nutritional needs, according to Mello and Norberg (2004), depends on the energy content of the diet that can be utilized by the ruminal microorganisms or be absorbed from the ruminal escape in other compartments of the digestive tract. The Cornell Net Carbohydrate and Protein System (CNCPS) is a system that considers the dynamics of ruminal fermentation and potential loss of nitrogen, as ammonia, in the evaluation of animal feeds (Sniffen et al., 1992), with the objective of adjusting ruminal digestion of carbohydrates and proteins to increase microbial production, reduce losses of $\mathrm{N}$ and estimate the ruminal escape of nutrients (Balsalobre et al., 2003). Although there have been numerous studies of the chemical composition of the forage grasses predominant in Brazil, there is little information available regarding their nutritive value, especially related to the fractionation of nutrients in function of the management conditions with use of nitrogen fertilizer.

The aim of this experiment was to characterize and identify the protein fractions contained in two pearl millet cultivars (ADR-300 and BN-1) submitted to different $\mathrm{N}$ doses and cutting ages, under the conditions in the municipality of Goiânia, Goiás state, Brazil.

\section{Material and Methods}

\subsection{Location and Start of the Experiment}

The experiment was conducted on the Model Farm of the Veterinary School of Goiás Federal University, in Goiânia, capital of the state of Goiás, Brazil. This region is located at $16^{\circ} 41^{\text {” S }}$ latitude and $49^{\circ} 17^{\prime}$ ' W longitude, at an altitude of $741 \mathrm{~m}$. The prevailing climate, according the classification of Köppen (1948), is Aw (hot and semi-humid, with a well-defined dry season from May to October). June is the coolest month, with an average temperature of 14.0 ${ }^{\circ} \mathrm{C}$, while September is the hottest month, with an average of $23.2{ }^{\circ} \mathrm{C}$, and the yearly average temperature is $17.9^{\circ} \mathrm{C}$. Mean annual rainfall is $1759 \mathrm{~mm}$ and mean annual relative humidity is $71 \%$, with the lowest index in August (Brasil, 1992). Meteorological data during the experimental period were monitored at the meteorological station of the School of Agronomy of Goiás Federal University.

The soil in the experimental area is classified as dystrophic Red Latosol (oxisol). For its chemical characterization, samples were collected at a depth of $0.20 \mathrm{~m}$. The chemical attributes were Ca: 2.7; Mg: 0.9; K: 0.13; Al: 0, H: 1.9 (all in $\mathrm{cmol}_{\mathrm{c}} \cdot \mathrm{dm}^{3}$ ), P (Mel): 17.5; K: 51 (in mg.dm ${ }^{3}$ ), $\mathrm{pH}\left(\mathrm{CaCl}_{2}\right)$ : 5.6; V (\%): 66.1 and $\mathrm{OM}$ (g/kg): 39.

To prepare the experimental field for sowing, the ground was plowed to an average depth of $0.20 \mathrm{~m}$ and then harrowed twice. Each experimental plot consisted of five rows measuring 5 meters in length spaced $0.40 \mathrm{~m}$ apart. Two millet cultivars were planted (ADR- 300 and $\mathrm{BN}-1)$. Treatments were composed of four doses of $\mathrm{N}\left(0,50,100\right.$ and $\left.150 \mathrm{~kg} \cdot \mathrm{ha}^{-1}\right)$, applied in the form of ammonium sulfate, and the plants were cut at three ages (31, 44 and 65 days after planting) above $0.25 \mathrm{~m}$ from soil surface. The experimental design was randomized blocks in a $4 \times 3$ factorial scheme with three repetitions.

The seeds were spread manually on January $16^{\text {th }}$, 2006, employing a seeding rate of 20 pure and viable seeds per linear meter. Ten days after emergence, side dressing of $60 \mathrm{~kg}^{-h^{-1}}$ of 
potassium chloride (KCl) was applied along with $36 \mathrm{~kg} \cdot \mathrm{ha}^{-1}$ of ammonium sulfate, followed by two more ammonium sulfate applications of $36 \mathrm{~kg} \cdot \mathrm{ha}^{-1}$ each after the first and second cutting.

\subsection{Preparation, Evaluation of the Samples and Laboratory Procedure}

For evaluation of the nutritional content, the plants were cut in the two central rows of each plot after eliminating the last $0.50 \mathrm{~m}$ at each end. The first cutting was performed 31 days after germination (March $8^{\text {th }}$, 2006), with the physiological age as the parameter for the moment that precedes the inflorescence emergence process. The second cutting was carried out 13 days later (March 21 $1^{\text {st }}$, 2006), while the third was performed 21 days after the second (April 11 ${ }^{\text {th }}$, 2006).

After each cutting, the material was identified and sent to the laboratory, where a sub-sample of approximately $500 \mathrm{~g}$ was taken from each sample. These portions were pre dried in a forced air chamber for 72 hours at $65{ }^{\circ} \mathrm{C}$. Then the dried material was ground in a Wiley mill and screened through a $1 \mathrm{~mm}$ mesh sieve. The content of dry matter (DM) and crude protein (CP) were determined according to the method described by Silva and Queiroz (2002). The concentrations of non-protein nitrogen (NPN), neutral detergent insoluble nitrogen (NDIN) and acid detergent insoluble nitrogen (ADIN) were measured according to the method described by Licitra et al. (1996). Soluble nitrogen (SN) was determined according to Krishnamoorthy et al. (1982), by the macro Kjeldahl technique. The neutral detergent and acid detergent fiber utilized to determine the nitrogen content were analyzed in a conventional fiber measurement device without using sodium sulfide. The analyses were performed at the Animal Nutrition Laboratory of the Veterinary School of Goiás Federal University.

The protein fractions were calculated by the Cornell system (CNCPS) (Sniffen et al., 1992). The protein was analyzed and calculated for the five fractions ( $A, B_{1}, B_{2}, B_{3}$ and $C$ ) as percentage of CP. Fraction A, composed of non-protein nitrogen (NPN) compounds, was determined by the difference between total $\mathrm{N}(\mathrm{tN})$ and the trichloroacetic acid (TCA) insoluble $\mathrm{N}$ according to the following formula: $\mathrm{A}(\% \mathrm{tN})=\mathrm{tN}-\mathrm{N}_{1} / \mathrm{Nt} \mathrm{x} 100$, where $\mathrm{tN}=$ total nitrogen and $\mathrm{N}_{1}=$ nitrogen insoluble in TCA. Fraction $\mathrm{B}_{1}$, referring to the proteins that are rapidly degraded in the rumen, was obtained by the difference between the nitrogen soluble in phosphate-borate buffer (PBB) and the NPN, calculated by the following formula: $B_{1}(\% N t)=N_{1}-N_{2} / N t \times 100$, where $N_{2}=$ nitrogen insoluble in PBB. Fractions $B_{2}$ and $B_{3}$, composed of the insoluble proteins with intermediate and slow degradation rates in the rumen, were determined by the difference between the fraction insoluble in PBB and the NDIN fraction and the difference between the NDIN and ADIN fractions, respectively. The respective formulas used to calculate $\mathrm{B}_{2}$ and $\mathrm{B}_{3}$ were: $\mathrm{B}_{2}(\% \mathrm{Nt})=\left(\mathrm{N}_{2}-\mathrm{NDIN}\right) / \mathrm{Nt} \mathrm{x} 100$ and $\mathrm{B}_{3}(\% \mathrm{Nt})=(\mathrm{NDIN}-\mathrm{ADIN}) / \mathrm{Nt} \times 100$. Fraction $\mathrm{C}$, composed of the proteins that are insoluble and indigestible in the rumen and gut, were determined by the residual nitrogen content of the sample after being treated with acid detergent (ADIN) and expressed as a percentage of the Nt of the sample. 


\subsection{Statistical Analysis}

The variables were submitted to analysis of variance and the means were compared by Student's t-test, at a 5\% level of significance. All the analyses were performed using the GLM procedure of the SAS software (2002).

\section{Results and Discussion}

Table 1 show the average $\mathrm{CP}$ and protein fraction values for the pearl millet cultivar ADR-300 submitted to $\mathrm{N}$ doses and cutting ages.

Table 1. Protein fractions (\%CP) of the pearl millet cv. ADR-300 under different nitrogen doses and cutting ages (31, 44 and 65 days).

\begin{tabular}{|c|c|c|c|c|c|c|}
\hline \multirow[b]{2}{*}{ Cuts } & \multicolumn{6}{|c|}{ N Doses $\left(\mathrm{kg} \cdot \mathrm{ha}^{-1}\right)$} \\
\hline & 0 & 50 & 100 & 150 & Regression & $\mathrm{R}^{2}$ \\
\hline & \multicolumn{6}{|c|}{ CP (\% DM) } \\
\hline 1 st & $11.82^{\mathrm{Dc}}$ & $13.26^{\mathrm{Cc}}$ & $14.84^{\mathrm{Bb}}$ & $17.07^{\mathrm{Ab}}$ & $y=0.0347 x+11.648$ & 99 \\
\hline 2nd & $14.54^{\mathrm{Da}}$ & $17.29^{\mathrm{Ca}}$ & $18.39^{\mathrm{Ba}}$ & $19.28^{\text {Аa }}$ & $y=0.0015 x 2-0.1662 x+12.019$ & 47 \\
\hline \multirow[t]{2}{*}{ 3rd } & $12.82^{\mathrm{Db}}$ & $14.19^{\mathrm{Cb}}$ & $15.27^{\mathrm{Bb}}$ & $16.75^{\mathrm{Ab}}$ & $y=0.0257 x+12.827$ & 99 \\
\hline & \multicolumn{6}{|c|}{ Fraction A (\% CP) } \\
\hline 1 st & $36.05^{\mathrm{Cb}}$ & $37.48^{\mathrm{Bb}}$ & $40.79^{\mathrm{Ab}}$ & $40.16^{\mathrm{Ac}}$ & $y=-0.0001 x 2+0.0518 x+35.851$ & 94 \\
\hline 2nd & $44.77^{\mathrm{Ba}}$ & $45.63^{\mathrm{Aa}}$ & $45.21^{\text {Аа }}$ & $43.50^{\mathrm{Ca}}$ & $\mathrm{y}=4 \mathrm{E}-05 \mathrm{x} 2+0.0031 \mathrm{x}+44.92$ & 72 \\
\hline \multirow[t]{2}{*}{ 3rd } & $26.18^{\mathrm{Dc}}$ & $32.81^{\text {Сc }}$ & $39.99^{\mathrm{Bc}}$ & $41.43^{\mathrm{Ab}}$ & $y=0.1059 x+27.163$ & 94 \\
\hline & \multicolumn{6}{|c|}{ Fraction $\mathrm{B}_{1}(\% \mathrm{CP})$} \\
\hline 1 st & $16.34^{\mathrm{Ba}}$ & $17.46^{\text {Аа }}$ & $15.15^{\mathrm{Ca}}$ & $16.75^{\mathrm{Ba}}$ & $y=5 E-05 x 2-0.0094 x+16.707$ & 41 \\
\hline 2nd & $7.56^{\mathrm{Ab}}$ & $7.35^{\mathrm{Ab}}$ & $6.33^{\mathrm{Bb}}$ & $5.67^{\mathrm{Cb}}$ & $y=-0.0134 x+7.731$ & 94 \\
\hline \multirow[t]{2}{*}{ 3rd } & $2.86^{\mathrm{Ac}}$ & $2.57^{\mathrm{Ac}}$ & $2.40^{\mathrm{Ac}}$ & $2.18^{\mathrm{Ca}}$ & $y=-0.0044 x+2.834$ & 98 \\
\hline & \multicolumn{6}{|c|}{ Fraction $\mathrm{B}_{2}(\% \mathrm{CP})$} \\
\hline 1 st & $10.28^{\mathrm{Cc}}$ & $10.14^{\mathrm{Ac}}$ & $9.68^{\mathrm{Ac}}$ & $6.08^{\mathrm{Bc}}$ & $y=-0.0003 x 2+0.0258 x+10.139$ & 97 \\
\hline 2nd & $19.75^{\mathrm{Bb}}$ & $18.90^{\mathrm{Bb}}$ & $21.35^{\mathrm{Ab}}$ & $18.58^{\mathrm{Cb}}$ & $y=-0.0002 x 2+0.0267 x+19.324$ & 21 \\
\hline \multirow[t]{2}{*}{ 3rd } & $41.52^{\text {Аа }}$ & $39.40^{\mathrm{Ba}}$ & $39.30^{\mathrm{Ba}}$ & $36.65^{\mathrm{Ca}}$ & $y=-0.0294 x+41.424$ & 91 \\
\hline & \multicolumn{6}{|c|}{ Fraction $\mathrm{B}_{3}(\% \mathrm{CP})$} \\
\hline 1 st & $23.73^{\mathrm{Bb}}$ & $20.06^{\text {Сc }}$ & $24.19^{\mathrm{Ba}}$ & $26.51^{\text {Aa }}$ & $y=0.0006 x 2-0.0649 x+23.25$ & 78 \\
\hline 2nd & $27.69^{\mathrm{Aa}}$ & $24.09^{\mathrm{Bb}}$ & $20.98^{\mathrm{Cb}}$ & $22.92^{\mathrm{Bb}}$ & $y=0.0006 x 2-0.1179 x+27.918$ & 96 \\
\hline \multirow[t]{2}{*}{ 3rd } & $28.64^{\mathrm{Ab}}$ & $26.13^{\mathrm{Ba}}$ & $25.27^{\mathrm{Ba}}$ & $25.75^{\mathrm{Ba}}$ & $y=0.0003 x 2-0.0639 x+28.625$ & 99 \\
\hline & \multicolumn{6}{|c|}{ Fraction C (\% CP) } \\
\hline 1 st & $6.06^{\mathrm{Ba}}$ & $7.08^{\text {Аа }}$ & $7.57^{\text {Аа }}$ & $5.16^{\mathrm{Ba}}$ & $y=-0.0003 x 2+0.047 x+5.9415$ & 92 \\
\hline 2nd & $2.57^{\mathrm{Ab}}$ & $1.81^{\mathrm{Ab}}$ & $2.71^{\mathrm{Ab}}$ & $1.96^{\mathrm{Ab}}$ & $y=-0.0019 x+2.402$ & 73 \\
\hline 3rd & $1.43^{\mathrm{Ab}}$ & $1.28^{\mathrm{Ab}}$ & $1.60^{\mathrm{Ab}}$ & $2.18^{\mathrm{Ab}}$ & $\mathrm{y}=4 \mathrm{E}-05 \mathrm{x} 2+0.0005 \mathrm{x}+1.1345$ & 99 \\
\hline
\end{tabular}

Capital letters in the rows and small letters in the columns differ from each other by the t-test at 5\% probability. CP: Crude Protein; DM: Dry Matter.

Table 2 show the average CP and protein fraction values for the pearl millet cultivar $\mathrm{BN}-1$ submitted to $\mathrm{N}$ doses and cutting ages. 
Table 2. Protein fractions (\%CP) of the pearl millet cv. BN-1 under different nitrogen doses and cutting ages (31, 44 and 65 days).

\begin{tabular}{|c|c|c|c|c|c|c|}
\hline \multirow[b]{2}{*}{ Cuts } & \multicolumn{6}{|c|}{ N Doses $\left(\mathrm{kg} \cdot \mathrm{ha}^{-1}\right)$} \\
\hline & 0 & 50 & 100 & 150 & Regression & $\mathrm{R}^{2}$ \\
\hline & \multicolumn{6}{|c|}{ CP (\% DM) } \\
\hline 1 st & $11.49^{\mathrm{Cc}}$ & $12.38^{\mathrm{Cb}}$ & $15.50^{\mathrm{Bb}}$ & $18.11^{\text {Аа }}$ & $y=11.137 e 0.0032 x$ & 97 \\
\hline 2nd & $14.24^{\mathrm{Ca}}$ & $17.07^{\mathrm{Ba}}$ & $18.31^{\mathrm{Aa}}$ & $18.75^{\mathrm{Aa}}$ & $y=-0.0002 x^{2}+0.0658 x+14.278$ & 99 \\
\hline \multirow[t]{2}{*}{ 3rd } & $12.41^{\mathrm{Cb}}$ & $12.18^{\mathrm{Cb}}$ & $14.78^{\mathrm{Bb}}$ & $16.02^{\mathrm{Ab}}$ & $y=0.0269 x+11.833$ & 86 \\
\hline & \multicolumn{6}{|c|}{ Fraction A (\% CP) } \\
\hline 1 st & $38.17^{\mathrm{Ba}}$ & $38.03^{\mathrm{Ba}}$ & $42.88^{\mathrm{Aa}}$ & $43.64^{\mathrm{Aa}}$ & $y=0.0425 x+37.491$ & 84 \\
\hline 2nd & $36.61^{\mathrm{Cb}}$ & $37.04^{\mathrm{Cb}}$ & $40.01^{\mathrm{Bb}}$ & $43.76^{\mathrm{Aa}}$ & $y=0.0488 x+35.692$ & 91 \\
\hline \multirow[t]{2}{*}{ 3rd } & $28.37^{\mathrm{Cc}}$ & $29.42^{\mathrm{Bc}}$ & $29.84^{\mathrm{Bc}}$ & $30.92^{\mathrm{Ab}}$ & $y=0.0161 x+28.427$ & 97 \\
\hline & \multicolumn{6}{|c|}{ Fraction $\mathrm{B}_{1}(\% \mathrm{CP})$} \\
\hline 1 st & $18.45^{\mathrm{Aa}}$ & $18.52^{\text {Aa }}$ & $17.81^{\mathrm{Aa}}$ & $16.15^{\mathrm{Ba}}$ & $y=-0.0152 x+18.874$ & 79 \\
\hline 2nd & $9.29^{\mathrm{Ab}}$ & $8.15^{\mathrm{Bb}}$ & $6.24^{\mathrm{Cb}}$ & $5.45^{\mathrm{Cb}}$ & $y=-0.0103 x+7.055$ & 90 \\
\hline \multirow[t]{2}{*}{ 3rd } & $6.88^{\mathrm{Ac}}$ & $6.86^{\mathrm{Ac}}$ & $5.91^{\mathrm{Bb}}$ & $5.48^{\mathrm{Bb}}$ & $y=-0.0103 x+7.055$ & 90 \\
\hline & \multicolumn{6}{|c|}{ Fraction $\mathrm{B}_{2}(\% \mathrm{CP})$} \\
\hline 1 st & $11.16^{\mathrm{Bc}}$ & $10.67^{\mathrm{Bc}}$ & $9.33^{\mathrm{Cc}}$ & $18.84^{\mathrm{Ac}}$ & $y=0.001 x 2-0.1066 x+11.745$ & 87 \\
\hline 2nd & $21.40^{\mathrm{Bb}}$ & $27.89^{\text {Aa }}$ & $27.64^{\mathrm{Ab}}$ & $21.79^{\mathrm{Bb}}$ & $y=-0.0012 x^{2}+0.1869 x+21.457$ & 99 \\
\hline \multirow[t]{2}{*}{ 3rd } & $28.38^{\mathrm{Aa}}$ & $25.63^{\mathrm{Bb}}$ & $29.09^{\text {Aa }}$ & $28.39^{\mathrm{Ba}}$ & $y=0.007 x+27.349$ & 86 \\
\hline & \multicolumn{6}{|c|}{ Fraction $\mathrm{B}_{3}(\% \mathrm{CP})$} \\
\hline 1 st & $25.68^{\mathrm{Ac}}$ & $25.20^{\text {Cc }}$ & $22.92^{\mathrm{Bb}}$ & $16.68^{\mathrm{Cc}}$ & $y=-0.0006 x 2+0.0278 x+25.572$ & 99 \\
\hline 2nd & $30.14^{\mathrm{Ab}}$ & $25.15^{\mathrm{Cb}}$ & $23.43^{\mathrm{Db}}$ & $26.84^{\mathrm{Bb}}$ & $y=0.0008 x 2-0.1492 x+30.233$ & 99 \\
\hline \multirow[t]{2}{*}{ 3rd } & $34.53^{\mathrm{Ba}}$ & $36.58^{\mathrm{Bb}}$ & $33.53^{\text {Са }}$ & $32.93^{\text {Da }}$ & $y=-0.0003 x 2+0.0241 x+34.908$ & 63 \\
\hline & \multicolumn{6}{|c|}{ Fraction C (\% CP) } \\
\hline 1 st & $6.54^{\mathrm{Ba}}$ & $7.58^{\text {Аa }}$ & $7.06^{\text {Аа }}$ & $4.69^{\mathrm{Ca}}$ & $y=-0.0003 x 2+0.039 x+6.5255$ & 99 \\
\hline 2nd & $2.56^{\mathrm{Ab}}$ & $1.77^{\mathrm{Ab}}$ & $2.68^{\mathrm{Ab}}$ & $2.16^{\mathrm{Ab}}$ & $y=3 E-05 x 2-0.0046 x+2.4035$ & 43 \\
\hline 3rd & $1.48^{\mathrm{Ac}}$ & $1.51^{\mathrm{Ab}}$ & $1.64^{\mathrm{Ac}}$ & $2.28^{\mathrm{Ab}}$ & $y=7 E-05 x 2-0.0062 x+1.5955$ & 98 \\
\hline
\end{tabular}

Capital letters in the rows and small letters in the columns differ from each other by the t-test at $5 \%$ probability. CP: Crude Protein; DM: Dry Matter.

The CP results were similar, with significant differences $(\mathrm{P}<0.05)$ between the doses applied and succession of cuttings for the cultivars. For both cultivars, the CP values increased at all cutting intervals, in which case the data fit both linear and polynomial models. The tables present all the regression equations for the ADR-300 and BN-1 cultivars in function of the $\mathrm{N}$ doses, where " $\mathrm{Y}$ " is the CP expressed as a percentage and " $\mathrm{X}$ " is the nitrogen dose.

The average CP values found for the ADR-300 and BN-1 cultivars varied from lows of 11.8 and $11.5 \%$ in the control treatment (no nitrogen dose) on the first cutting to highs of 19.3 and $18.7 \%$ at a dose equivalent to application of $150 \mathrm{~kg} \cdot \mathrm{ha}^{-1}$ of $\mathrm{N}$ on the second cutting, respectively. The ADR-300 cultivar had higher $\mathrm{CP}$ levels than the $\mathrm{BN}-1$ cultivar, probably because of its lesser potential to produce dry mass, thus not presenting the dilution effect. 
Silva et al. (2009) found levels of crude protein ranging from 8.7 to $10.6 \%$ and from 7.5 to $10.2 \%$ when evaluating Mombasa grass at cutting heights of 0.20 and $0.40 \mathrm{~m}$, respectively, with application of a nitrogen dose of up to $500 \mathrm{~kg} / \mathrm{ha}$. In turn, Velasquez et al. (2010) reported CP values ranging from 9.5 to $16.9 \%$ when evaluating three tropical forage grasses: Tanzania grass, Marandu grass and Tifton grass, at three cutting ages (28, 35 and 42 days), with application of $60 \mathrm{~kg}$ of $\mathrm{N} / \mathrm{ha}$. The CP values measured by those authors were lower than those determined for the two cultivars in the present work, where the $\mathrm{N}$ doses were lower, demonstrating the high physiological capacity of pearl millet, even in the control treatment.

Fraction A (NPN) for the pearl millet cultivars ADR-300 and BN-1 submitted to different $N$ doses and cut at different ages presented a positive response $(\mathrm{P}<0.05)$ and fit both the polynomial and linear regression model. Tables 1 and 2 present the regression equations for fraction $\mathrm{A}$ of the ADR-300 and $\mathrm{BN}-1$ cultivars of pearl millet in function of the $\mathrm{N}$ doses, where " $\mathrm{Y}$ " is fraction $A$, expressed as a percentage, and " $\mathrm{X}$ " is the nitrogen dose. This fraction, characterized for having high ruminal degradability, showed higher values in the second cutting for $\mathrm{Cv}$. ADR-300 and the first cutting for $\mathrm{cv}$. BN-1, at all doses evaluated. As the $\mathrm{N}$ dose increased, the percentages of this fraction rose in both cultivars, probably due to the greater presence of free amino acids and small peptides in the plant tissue in function of the uptake of $\mathrm{N}$ from the soil. The only exception was the second cutting, in which the highest value occurred at a dose of $50 \mathrm{~kg} \cdot \mathrm{ha}^{-1}$ for cv. ADR-300. This rising response of fraction A can indicate high losses of $\mathrm{N}$ in the form of ammonia by ruminants at the higher $\mathrm{N}$ doses. According to Russel et al. (1992), the ruminal microorganisms that ferment structural carbohydrates utilize ammonia as a source of N. However, high proportions of non-protein nitrogen can result in greater losses of nitrogen compounds due to lack of a readily available carbon skeleton for microbial protein synthesis to occur. Hence, there should be synchronous supply of proteins and carbohydrates in the rumen for better utilization of food, making it necessary to supply carbohydrates that degrade rapidly when the forage presents high levels of fractions $\mathrm{A}$ and $\mathrm{B}_{1}$.

Skonieski et al. (2006) evaluated pearl millet cultivars at different cutting ages with application of $80 \mathrm{~kg} . \mathrm{ha}^{-1}$ of $\mathrm{N}$ and determined fraction values ranging between 18.6 to $45.6 \%$, a similar range as that found in the present study. Sá et al. (2010) assessed three tropical forage grasses (Tanzania, Marandu and Tifton) at two cutting ages (28 and 35 days) and reported values from 19.5 to $28.7 \%$ for fraction A, also within the range found in this study.

Fraction $\mathrm{B}_{1}$ for the ADR-300 and BN-1 cultivars submitted to different $\mathrm{N}$ doses and cutting ages also presented a positive response $(\mathrm{P}<0.05)$ and fit both the polynomial and linear regression models. Tables 1 and 2 present the regression equations for fraction $\mathrm{B}_{1}$ of cultivars ADR-300 and BN-1, respectively, in function of the $\mathrm{N}$ doses, where " $\mathrm{Y}$ " is fraction $\mathrm{B}_{1}$, expressed as a percentage, and " $\mathrm{X}$ " is the nitrogen dose. Fraction $\mathrm{B}_{1}$, composed of globulins and some albumins, soluble proteins that are rapidly degraded in the rumen, presented interaction with the $\mathrm{N}$ doses and cutting ages, with higher values in the first cutting in relation to the others for both cultivars. As the nitrogen doses increased, the values of fraction $B_{1}$ diminished, with the exception of the first cutting, where the lowest value was observed for the dose of $100 \mathrm{~kg}^{-h a^{-1}}$ of $\mathrm{N}$ for cv. ADR-300. 
These results can indicate that the $\mathrm{N}$ applied did not have a significant participation in the accumulation of soluble protein and that a physiological stress of the grass came to predominate as the cutting age increased. The average values for fraction $\mathrm{B}_{1}$ in $\mathrm{cv}$. ADR-300 varied from $2.2 \%$ at a dose of $150 \mathrm{~kg}^{-h^{-1}}$ of $\mathrm{N}$ in the third cutting to $17.5 \%$ with application of $50 \mathrm{~kg} \cdot \mathrm{ha}^{-1}$ of $\mathrm{N}$ in the first cutting, while for $\mathrm{cv}$. BN-1 the range was from $5.4 \%$ in the second cutting at a dose of $150 \mathrm{~kg} \cdot \mathrm{ha}^{-1}$ of $\mathrm{N}$ to $18.5 \%$ in the first cutting at a dose of 50 kg.ha ${ }^{-1}$ of N. Skonieski et al. (2006) evaluated fraction $B_{1}$ of two millet cultivars and measured values between 4.7 and 10.4\%, while Velaquez et al. (2010) reported values from 1.6 to $2.3 \%$ for this protein fraction for Tanzania, Marandu and Tifton grass after 28 days of growth.

For the true protein with intermediate degradation rate (fraction $\mathrm{B}_{2}$ ), there was a significant interaction $(\mathrm{P}<0.05)$ between the $\mathrm{N}$ doses and cutting ages, with values ranging from 6.08 and 9.3\% to 41.5 and $29.1 \%$ of CP for cv. ADR-300 and BN-1, respectively. These data again fit both the quadratic and linear regression models. The regression equations for fraction $\mathrm{B}_{2}$ of the ADR-300 and BN-1 cultivars, in function of the $\mathrm{N}$ doses, are presented in Tables 1 and 2, respectively, where " $\mathrm{Y}$ " is fraction $\mathrm{B}_{2}$, expressed as a percentage, and $\mathrm{X}$ " is the nitrogen dose.

A higher quantity of fraction $\mathrm{B}_{2}$ in the plant indicates there is less protein bound to fiber and thus more true protein available to microorganisms in the rumen. Skonieski et al. (2006) found values of fraction $\mathrm{B}_{2}$ varying from 17.6 to $32.4 \%$. In a study of Tanzania grass, Silva et al. (2009) reported fraction $B_{2}$ levels ranging from 14.1 to $24.6 \%$ when the plants were cut at heights of 0.20 and $0.40 \mathrm{~m}$, with application of up to $500 \mathrm{~kg} \cdot \mathrm{ha}^{-1}$ of $\mathrm{N}$, while Velasquez et al. (2010), studying Tanzania, Marandu and Tifton grass, with application of $60 \mathrm{~kg} \cdot \mathrm{ha}^{-1}$ of N, measured percentages of 23.8 to $31.8 \%$ for the same fraction.

As for fraction $\mathrm{B}_{2}$ (mostly consisting of albumins and glutelins), differences were also observed for fraction $\mathrm{B}_{3}$ (insoluble proteins with slow degradation rate, composed of extensins, prolamins and denatured proteins) between $\mathrm{N}$ doses and cutting ages. The highest values of this fraction occurred in the control treatment, except for the first cutting of $\mathrm{cv}$. ADR-300 and the third cutting of $\mathrm{cv}$. BN-1.

For both cultivars, fraction $\mathrm{B}_{3}$ differed significantly $(\mathrm{P}<0.05)$ between the treatments and cutting ages, with values ranging from $20.1 \%$ with application of $50 \mathrm{~kg}^{-h^{-1}}$ of $\mathrm{N}$ in the first cutting to $28.6 \%$ in the control treatment in the third cutting for cv. ADR-300 and from $16.7 \%$ with application of $150 \mathrm{~kg} \cdot \mathrm{ha}^{-1}$ of $\mathrm{N}$ in the first cutting to $36.6 \%$ at a dose of $50 \mathrm{~kg} \cdot \mathrm{ha}^{-1}$ of $\mathrm{N}$ in the third cutting for $\mathrm{cv}$. BN-1. The data for fraction $\mathrm{B}_{3}$ between the treatments and cutting ages fit only the polynomial regression model. Tables 1 and 2, respectively, present the regression equations for fraction $\mathrm{B}_{3}$ of the $\mathrm{ADR}-300$ and $\mathrm{BN}-1$ cultivars in function of the $\mathrm{N}$ dose, where " $\mathrm{Y}$ " is fraction $\mathrm{B}_{3}$, expressed as a percentage, and " $\mathrm{X}$ " is the nitrogen dose. Skonieski et al. (2006) reported fraction $\mathrm{B}_{3}$ values varying from 16.9 to $29.5 \%$, while Silva et al. (2009) measured levels ranging from 20.8 to $44.5 \%$ for Tanzania grass cut after 28 days of growth and fertilized with up to $500 \mathrm{~kg} \cdot \mathrm{ha}^{-1}$ of $\mathrm{N}$.

Fraction $\mathrm{C}$, formed by insoluble proteins that are not digestible in the rumen and gut, presented a significant difference $(\mathrm{P}<0.05)$ between the $\mathrm{N}$ doses and cutting ages studied, 
with higher values in the first cutting for both cultivars. The data for fraction $\mathrm{C}$ between treatments and cutting ages fit both the polynomial and linear regression models. Tables 1 and 2 , respectively, present the regression equations for fraction $\mathrm{C}$ of the ADR-300 and BN-1 cultivars in function of the $\mathrm{N}$ dose, where " $\mathrm{Y}$ " is fraction $\mathrm{C}$, expressed as a percentage, and " $X$ " is the nitrogen dose. There was a decline in this fraction in function of the older cutting age, except for the third cutting of the plants receiving a dose of $150 \mathrm{~kg}$.ha ${ }^{-1}$ of $\mathrm{N}$ for $\mathrm{cv}$. ADR-300, but without a significant difference. The values of fraction $\mathrm{C}$ ranged from $1.3 \%$ to $7.57 \%$ for cv. ADR-300 and $1.5 \%$ to $7.6 \%$ for cv. BN-1.

Silva et al. (2009) reported fraction C values of 8.4 to $11.4 \%$ when evaluating Tanzania grass cut at two residual heights, under nitrogen fertilization, while Velasquez et al. (2010) measured values from 19.7 to $27.0 \%$ for fraction C in a study of Tanzania, Marandu and Tifton grass cut after 28 days with application of only $60 \mathrm{~kg} \cdot \mathrm{ha}^{-1}$ of $\mathrm{N}$.

Nevertheless, according to Van Soest (1994), from 5 to 15\% of the total $\mathrm{N}$ of forage grasses is bound to lignin, making it totally unavailable. The values found for the second and third cuttings here are below the lower limit of this interval. Therefore, the percentage of total nitrogen bound to lignin in both cultivars can be considered low.

\section{Conclusion}

The increase in nitrogen fertilization increased the crude protein content and influenced the protein fractions, as did the cutting age. There was a smaller indigestible protein fraction in both cultivars in the second and third cuttings.

\section{Acknowledgments}

We express our sincere thanks to the company Sementes Adriana for donating the seeds and reagents used in the study.

\section{References}

Balsalobre, M. A. A., Corsi, M., Santos, P. M., Vieira, I. \& Cárdenas, R. R. (2003). Composição química e fracionamento do nitrogênio e dos carboidratos do capim-tanzânia irrigado sob três níveis de resíduo pós-pastejo. Revista Brasileira de Zootecnia, 32(3), 519-528. http://dx.doi.org/10.1590/S1516-35982003000300003

Benedetti, E. (1999). Uso do milheto como fonte alternativa de produção de leite a pasto. Workshop Internacional de Milheto - Embrapa, pp. 105-108.

Brasil. Ministério da Agricultura e Reforma Agrária. Secretaria Nacional de Irrigação, Departamento Nacional de Meteorologia. (1992). Normais Climatológicas: 1961-1990. Brasília: MAPA.

Corsi, M. (1995). Adubação nitrogenada das pastagens. In A. M. Peixoto, J. C. Moura, \& V. P. Faria, Pastagens: fundamentos da exploração racional (2nd ed., pp. 121-153). Piracicaba, Brasil: Fealq.

Ferolla, F. S., Velasques, H. M., Silva, J. F. C., Viana, A. P., \& Domingues, F. N. (2008). 
Composição bromatológica e fracionamento de carboidratos e proteínas de aveia-preta e triticale sob corte e pastejo. Revista Brasileira de Zootecnia, 37(2), 197-204. http://dx.doi.org/10.1590/S1516-35982008000200004

Gonçalves, G. D., Santos, G. D., Jobim, C. C., Cecato, U., Damasceno, J. C., Branco, A. F., \& Silva, K. T. (2001). Determinação das frações de proteína e de carboidratos de gramíneas do gênero Cynodon em diferentes idades de corte. Acta Scientiarum, 23(4), 789-794.

Kollet, J. L., Diogo, J. M. \& Leite, G. G. (2006). Rendimento forrageiro e composição bromatológica de variedades de milheto (Pennisetum glaucum (L.) R. BR.). Revista $\begin{array}{llll}\text { Brasileira de Zootecnia, } & \text { 35(4) }\end{array}$ http://dx.doi.org/10.1590/S1516-35982006000500008

Köppen, W. (1948). Climatologia: con un estudio de los climas de la Tierra. México D. F.: Fondo de Cultura Económica.

Krishnamoorthy, U. C., Muscato, T. V., Snifen, C. J., \& Van Soest, P. J. (1982). Nitrogen fractions in selected feedstuffs. Journal of Dairy Science, 65(1), 217-225. http://dx.doi.org/10.3168/jds.S0022-0302(82)82180-2

Licitra, G., Hernandez, T. M., \& Van Soest, P. J. (1996). Standardization of procedures for nitrogen fractionation of ruminant feeds. Animal Feed Science and Technology, 57(4), 347-358. http://dx.doi.org/10.1016/0377-8401(95)00837-3

Mello, R., \& Nörnberg, J. L. (2004). Fracionamento dos carboidratos e proteínas de silagens de milho, sorgo e girassol. Ciência Rural, 34(5), 1537-1542. http://dx.doi.org/10.1590/S0103-84782004000500033

Moojen, E. L., Restle, J., Lupatini, G. C., \& Moraes, A. G. (1999). Produção animal em pastagem de milheto sob diferentes níveis de nitrogênio. Pesquisa Agropecuária Brasileira, 34(11), 2145-2149. http://dx.doi.org/10.1590/S0100-204X1999001100022

Russell, J. B., O’Connor, J. D., Fox, D. G., Van Soest, P. J. \& Sniffen, C. J. (1992). A net carbohydrate and protein system for evaluating cattle diets: I. Rumen fermentation. Journal Animal. Science, 70(11), 3551-3561.

Sá, J. F., Pedreira, M. S., Silva, F. F., Bonomo, P., Fiqueiredo, M. P., Menezes, D. R., \& Almeida, T. B. (2010). Fracionamento de carboidratos e proteínas de gramíneas tropicais cortadas em três idades. Arquivo Brasileiro de Medicina Veterinária e Zootecnia, 62(3), 667-676. http://dx.doi.org/10.1590/S0102-09352010000300023

Statistical Analysis Sistem Institute Incorporated (2001). What's new in SAS: release 8.1 and 8.2.Cary, NC, SAS Institute.

Silva, A. G., França, A. F. S., Miyagi, E. S., Mello, S. Q. S., Ferreira, J. L. \& Carvalho, E. R. (2009). Frações protéicas da capim-Mombaça submetido a doses de nitrogênio em duas alturas de corte. Arquivo Brasileiro de Medicina Veterinária e Zootecnia, 61(5), 1148-1155. http://dx.doi.org/10.1590/S0102-09352009000500018 


\section{Macrothink}

Silva, D. J., \& Queiroz, A. C. (2002). Análises de alimentos (métodos químicos e biológicos). (3rd ed.) Viçosa, Brasil: UFV.

Silva, S. C., Nascimento Júnior, D., \& Euclides, V. P. B. (2008). Pastagens: conceitos básicos, produção e manejo. Viçosa, Brasil: Suprema.

Skonieski, F. R., Nörnberg, J. L., Kessler, J. D., Azevedo, E. B., Borstmann, J. W., \& Pedó, L. F. (2006) Fracionamento da parede celular e da proteína de cultivares de milheto e sorgo sob regime de cortes. In: Annals of the $43^{\text {rd }}$ Brazilian Animal Science Annual Meeting. CD-rom, João Pessoa, Brasil. SBZ.

Sniffen, C. J., O’Connor, J. D., Van Soest, P. J., Fox, D. G., \& Russell, J. B. (1992). A net carbohydrate and protein system for evaluating cattle diets: II. Carbohydrate and protein availability. Journal of Animal Science, 70(11), 3562-3577.

Van Soest, P. J. (1994). Nutritional Ecology of the Ruminant. (2nd ed.) Ithaca: Cornell University Press.

Velasquez, P. A. T., Berchielli, T. T., Reis, R. A., Riviera, A. R., Dian, P. H. M., \& Teixeira, I. A. M. A. (2010). Composição química, fracionamento de carboidratos e proteínas e digestibilidade in vitro de forrageiras tropicais em diferentes idades de corte. Revista $\begin{array}{llll}\text { Brasileira de } \quad \text { Zootecnia, } & \text { 39(6), }\end{array}$ http://dx.doi.org/10.1590/S1516-35982010000600007

\section{Copyright Disclaimer}

Copyright reserved by the author(s).

This article is an open-access article distributed under the terms and conditions of the Creative Commons Attribution license (http://creativecommons.org/licenses/by/3.0/). 